\title{
Skeletal radiology special publications
}

\author{
Mark J. Kransdorf ${ }^{1}$
}

Published online: 13 November 2021

(c) ISS 2021

It is a distinct honor and a great pleasure to introduce our readers to a new, recurring feature being introduced in this issue of the Journal.

With the initiation of the Founders' Fellowship in musculoskeletal journalism, the Editors and the Journal, in conjunction with the staff of Springer Nature, developed a commissioning strategy for the Journal, incorporating it into the Editorial Fellowship. If you are not familiar with this practice, "commissioning" is the process in which well-respected experts in particular areas are asked to submit articles on topics or advances within their area of expertise.
In this issue of the Journal, we present our inaugural commissioned special section, organized by our first Editorial Fellow (and her editor mentors), titled "multiple myeloma." This will be followed in February, by a special issue on "artificial intelligence." I hope you find these commissioned publications enlightening, as well as clinically relevant.

Publisher's note Springer Nature remains neutral with regard to jurisdictional claims in published maps and institutional affiliations.
Mark J. Kransdorf

kransdorf.mark@mayo.edu

1 Mayo Clinic, Phoenix, AZ, USA 